\title{
AS ELEIÇÕES E O DISCURSO DA ÉTICA APONTAMENTOS SOBRE A "POROSIDADE" ENTRE AS ESFERAS POLÍTICA E RELIGIOSA
}

\author{
José Rogério Lopes*
}

Resumo: $\mathrm{O}$ artigo discute e analisa o contexto dos discursos sobre a questão ética, na campanha eleitoral de 2006, no Brasil, com ênfase na propaganda eleitoral gratuita de rádio e TV. Tal análise busca compreender as referências que produziram uma convergência discursiva, na campanha eleitoral, em torno do tema da ética, evidenciando que houve um deslocamento da discussão, do campo de conflitos entre posicionamentos políticos e concepçôes de mundo para o da privatização das responsabilidades éticas, segundo uma hierarquia de valores atribuídos aos cargos em eleição. Nesse contexto, aponta-se que a discussão da questão ética está marcada pela "porosidade" das interações entre as esferas políticas e religiosas de nossa sociedade, difusas nos campos de ação, mas convergentes em torno da exigência social do que é moralmente justo.

Palavras-chave: Ética, eleições, pluralismo, política, religião.

A campanha eleitoral de 2006, no Brasil, inscrita em um momento de profunda turbulência nas instituições políticas, em virtude das denúncias de corrupção que abalaram o governo federal, apresentou uma convergência dos discursos eleitorais em torno da questão ética.

Sobretudo, no período de propaganda eleitoral gratuita no rádio e na TV, a maioria dos candidatos aos cargos de deputados estaduais e federais, senadores, governadores e presidente da república incluíram, em suas exposiçóes, algum motivo de denúncia em torno desses fatos ${ }^{1}$.

Considerando este contexto dos discursos de campanha eleitoral, busco discutir se tal convergência foi produzida como apelo ao caráter secularizado e público da ética, a

\footnotetext{
* Professor Titular do PPG em Ciências Sociais da Unisinos, RS.

${ }^{1}$ Registro tais fatos: embora o centro das "denúncias", na campanha el eitoral, tenha sido o chamado escândalo do Dossiê, outros casos recentes devem ser lembrados. Desde 2005: o chamado caso Valdomiro, referente ao então assessor de José Dirceu enquanto Ministro da Casa Civil; o caso dos dólares na cueca de petistas detidos em um aeroporto brasileiro; o caso Mensalão, que derrubou o presidente do PT, José Genoíno, além de outros deputados federais e o Ministro da Fazenda, Antônio Palocci; o caso da Máfia das ambulâncias, ou dos Sanguessugas, envolvendo políticos de diversos partidos.
}

Debates do NER, Porto Alegre, ANo 7, N. 10, P. 89-104, Jul./DeZ. 2006 
chamada ética civil, enfatizada em tempos de denúncias de corrupção, ou se, por outro lado, tal convergência se produziu na razão de um revigoramento do caráter religioso de orientação das condutas.

\section{A CAMPANHA ELEITORAL E OS DISCURSOS SOBRE A QUESTÃO ÉTICA}

Durante o período de propaganda gratuita no rádio e na tv, na campanha eleitoral de 2006, a maioria dos candidatos enfatizou a questão ética, sobretudo orientando seus discursos contra os escândalos recentes envolvendo pessoas em cargo no governo federal, ou dos partidos de sustentação do governo.

Os meses de propaganda gratuita expuseram, em cadeia de rádio e TV, candidatos oriu ndos de vários partid os dis au rsando sobre a urgência de: "limpar a política", "expurgar os maus políticos das assembléias legislativas e do congresso", "moralizar as instituições políticas", "usar o voto para demonstrar indignação com a corrupção", "dar um basta à roubalheira", "votar em político honesto", en tre outras. A maioria dos candidatos apresentou-se como "al ter nativa a ess e quadro de ausência de ética", como "a sol ução para o problema da corru pção", en quanto outros enfatizaram "a necessidade de recuperar a credibilidade da política" ou de "exercitar a cidadania em prol do bem público". Outros, mais intempestivos, responsabilizaram os eleitores pelos feitos dos políticos em que eles votaram, afirmando que era "preciso tomar vergon ha na cara e votar certo".

Embora o conjunto dos discursos confluísse para um campo de oposição ao governo e a o PT, a maioria dos candidatos buscou significar suas "denúncias" e seus ataques com uma carga de in dignação social con tra "o estado atual de corrupção generalizada". Dessa perspectiva, foi evitada a polarização em torno dos termos direita/esquerda, como conceitos que descrevem a realidade e prescrevem a ação em campos de orientação e interesses políticos distintos (Bobbio, 1995, p. 27). Em seu lugar, prevaleceu uma ilusão tecnocrática, como aquela estabelecida pela divisão entre progressistas e conservadores, segundo a qual as oposiçôes políticas são descritas por "agregações com base não em posições, mas em problemas" (Bobbio, 1995, p. 34).

Muitos candidatos buscavam, com essa estratégia discursiva, obscurecer as posições antitéticas que designam "o contraste entre as ideologias e entre os movimentos em que se divide o un iverso, eminentemente conflitual, do pensamento e das açôes políticas" (Bobbio, 1995, p. 31), de forma a evitar serem reconhecidos como compondo o espectro de direita ou de esquerda. Esse movimento lhes permitiu expressar uma pretensa legitimidade em vocalizar os sentimentos coletivos, afirmando em um momento ou outro estar "cansado de ouvir, por onde passo, a população se queixar dos políticos corruptos", ou de "falar por aqueles que não têm a oportunidade que eu tenho".

Além dessa variada enumeração de necessidades, motivos, responsabilidades, culpas e posicionamentos, importa perceber que, com raras exceções (como em alguns políticos do PT, do PCdoB, do PDT, do PSB, do PSOL e do PV, que projetaram um quadro

Debates do NER, Porto Alegre, ANo 7, N. 10, P. 89-104, Jul./DEZ. 2006 
partidário de responsabilização das condutas políticas), a maioria dos candidatos que insistiram no discurso da ética, projetavam a si próprios como a opção correta ao eleitor: "eu ten ho moral para ser seu candid ato", "minha biografia é minha justificativa para pedir teu voto", "quem me conhece, sabe que pode confiar em mim", "eu vou mudar essa sit uação", "eu vou ser seu repres en tante contra esse estado de cois as", "eu vou lutar contra a cor rupção", "eu tenho tradição de defesa da ética”, e assim seguiu.

Essa privatização das responsabilidades éticas, muito ao gosto de um discurso e uma prática política contemporânea e determinada, desdobra-se das ambigüidades produzidas nas relações entre legitimidade versus ilegitimidade na representação política, que constituem um paradoxo da democracia, entre a formalidade e a substância - paradoxo que se manifesta, regularmente, no exercício do governo (Bobbio, 1986).

Na medida em que o governo civil se constituiu e se configurou, nas sociedades democráticas, como governo do poder público em público, o ordenamento público do poder, na democracia contemporânea, supõe que este poder seja "manifesto": seja na forma de representação, seja na de descentralização, e que se deve submeter à publicizaçáo, na razão exposta por Kant (1990), recentemente revisitada por Habermas (2004), entre outros.

Nesse sentido, as "denúncias" de escândalos políticos, como na ca mpanha eleitoral, buscariam publicizar o antes secreto "poder invisível" (Bobbio, 1986, p. 91) que age no governo contra o bem público.

Aquelas ambigüidades, por sua vez, ao se desdobrarem nos discursos de campanha como os acima expostos, reforçam o número limitado das fórmulas lógicas que se operam nos "mecan ismos combinatór ios da imaginaçáo coletiva" (Girardet, 1987, p. 17) e se reproduzem como representações sociais do tipo: "[...] se existe uma sombra ameaçadora, existe também uma sombra tutelar" (Girardet, 1987, p. 16). E como "a democracia não pode press up or a ausência de disputas, de projetos e visôes discordantes" (Vitullo, 1999, p. 35), os discursos desses candidatos obscurecem as ambigüidades e polarizam as representações sociais em campos valorativos distintos e em luta, apelando para uma tomada de posição do eleitor: "essa situação não pode mais continuar, você tem que decidir!". O problema é que a decisão referia-se a uma "luta do bem contra o mal", e não, ao processo de comparação e escolha de um projeto de governo, característico da eleição (Ribeiro, 2006).

As imagens veiculadas pelos partidos de oposição ao governo, expondo os sujeitos envolvidos nos casos de corrupção, em uma síntese sincrônica destes casos (aliás, estratégia utilizada pelo próprio partido no governo, em campanhas passadas), complementavam esse quadro. Dessa forma, a recorrência à questáo ética nos discursos dos candidatos, na campanha eleitoral, parecia convergir para a representação social da denúncia suprapartidária de um "complô contra a democracia", de um "golpe do gover no e do PT contra aqueles que votaram na esperança de mudança”. Na afirmação recorren te da candidata à Presidência da República pelo PSOL, como "uma traição à população que depositou sua esperança neste governo".

Esta representação social, por sua vez, era reforçada pela recorrência das denúncias de corrupção, que se originavam de várias posiçōes partidárias. Mas, por outro lado, se adequava a um jogo de reconhecimento (no escopo de relações partidárias dos sujeitos envolvidos nos casos de corrupção, ou daqueles que os denunciavam), em níveis de atuação e representação políticas distintos, na competição eleitoral. Assim, o candidato ao

Debates do NER, Porto Alegre, ano 7, N. 10, P. 89-104, jul./Dez. 2006 
senado pela coligação encabeçada pelo PSDB, no estado do Rio Grande do Sul, dirigia em seus programas ataques e denúncias contra o governo federal, sustentados na representação acima elaborada. Porém, quando este mesmo candidato dirigia seu discurso contra o candidato do PMDB à reeleição para o mesmo cargo, que iniciou sua campanha firmando-se na "postu ra ética que sempre marcou sua atuação política", afirmava recor rentemente em seu programa que "não basta ser ético". Repetidamen te, o candidato daquela coligação apelava ao eleitor para que lembrasse de algum projeto do senador do PMDB, há 24 anos no cargo, em prol do Rio Grande do Sul.

A seqüência do embate entre esses candidatos logo mostrou efeitos. Assim que os dis au rsos do tipo "Não basta ser ético, tem que mostrar serviço e representatividade!" foram se intensificando e convergindo, na campanha eleitoral, contra o candidato do PMDB, seus programas abandonaram a defesa da postura ética e começaram a mostrar projetos de leis elaborados pelo mesmo e aprovados.

Uso este exemplo para mostrar que a questão ética transitou, durante a campanha eleitoral, de uma tendência à convergência no plano geral dos discursos contra a corrupção e os corruptos (centrados no governo federal e no PT), para uma privatização das responsabilidades éticas em torno dos candidatos que afirmavam possuir perfil político para o enfren tamento necessário desse "complô contra a democracia". Porém, enquanto a tendên cia geral dos discursos de campanha convergiu para ataques à candidatura majoritária do partido no governo, em outros níveis de candidatura, regionalizados, os ataques se diluíram em discursos e enfrentamentos que tornaram secundária a premência da questão ética.

Nesse sentido, cabe reconhecer que as relações entre legitimidade versus ilegitimidade na representação política seguem a configuração social de uma hierarquia de valores sustentada nas atividades em que a questão ética se forma e reproduz, ou se projeta. Ou seja, ela pode ser um bem, ou um valor, e nesse sentido, como já indicou Godelier (1974, p. 79), “a hierarquia dos bens expressa [...] a hierarquia dos valores ligados às diversas atividades sociais e esses valores traduzem o papel dominante no seio da sociedade de certas estruturas sociais".

Ora, se essa compreensão está coerentemente elaborada, torna-se necessário identificar que estruturas sociais estão assumindo papéis dominantes nesses discursos de campanha. $\mathrm{E}$ mais, se os valores ligados às atividades políticas em eleição, nesse período, estão sendo traduzidos em acordocom as estruturas sociais colocadas em destaque nos discursos dos candidatos.

A primeira questão se responderia por uma constatação evidente, para muitos: a diversidade dos candidatos que expuseram a questão ética como central em seus discursos de campanha, originados de quadros partidários os mais variados, no universo conflitual do pensamento e das ações políticas, sugere que há uma problematização social consensual em torno da esfera política, impregnada de corrupção.

Contudo, o trânsito da questão ética por entre a hierarquia de valores atribuídos aos cargos em eleição, na campanha eleitoral, mostra que esta resposta não é tão evidente assim, uma vez que ela assumiu centralidade na eleição para o cargo majoritário da nação, sendo muitas vezes desprezada na competição eleitoral para os demais cargos.

A referência concreta para que pudéssemos aceitar a resposta acima deveria ser constatada em uma esfera mais ampla de reconhecimento, ou seja, aquela da "predisposição para in terven ção", que Sandoval (1994, p. 68) definiu como "o componente de con duta

Debates do NER, Porto Alegre, ANo 7, N. 10, P. 89-104, Jul./DEZ. 2006 
da consciência, no sentido que focaliza o rapport dos indivíduos com formas de ação sancionadas pelo mesmo na defesa de seus interesses". Dito de ou tra forma, esse pretenso consenso deveria ter catalisado formas coletivas de manifestação da indignação da população (pretensamente vocalizadas por muitos dos candidatos), frente à questão ética problematizada na campanha eleit oral como um "complô contra a democracia". O registro histórico recente do caso Collor mostra que essa relação tem fundamento.

A ausência dessas manifestações leva, então, à necessidade de rever a noção de consciência em movimento, nesse processo, porque

[...] o conceito de consciência está intimamente relacionado ao engajamento do comportamento social em busca de auto-interesse e de interesse de classe. Além disso, a compreensáo de como certas açōes individuais ou coletivas ocorrem ou deixam de ocorrer não é apenas uma questáo de circunstância histórica ou da percepção do indivíduo de sua realidade social, mas também do repertório disponível de açôes possíveis e da legitimidade atribuída às mesmas por seus atores. [...] Na consolidação de processos democráticos como no caso brasileiro, a noção de predisposiçáodo ci dadâo para 'intervir' to ma-se umaspecto central do modocomo os brasileiros percebem sua situação e soluções possíveis (Sandoval, 1994, p. 68).

Nesse ponto, o que esta campanha eleitoral mostrou foi que candidatos da direita e de setores da esquerda alijados do governo, ou seus opositores, orientaram seus discursos mais em proveito próprio ${ }^{2}$. A maior parte dos candidatos apresentou como solução para a polarização ética versus corrupção, a idéia de renovação, que permite privatizar responsabilidades éticas na forma de um capital simbólico, exposto invariavelmente na campanha como distinção (Bourdieu, 1991).

A preocupação dos candidatos em se distinguir dos demais concorrentes e se mostrarem mais adequados ao gosto dos eleitores, reforçando o discurso da renovação dos atores, sem aprofundar o debate sobre a necessidade de superar vícios da estrutura política, visou restringir o repertório disponível das ações individuais e coletivas possíveis e sua legitimação, configurando os limites conjunturais de um mercado eleitoral ${ }^{3}$. Nesse sentido, a campanha eleitoral expôs out ra versão da "luta por reconhecimen to" propugnada por Honneth (2003): a luta dos políticos pelo reconhecimento dos eleitores, no seu exercício do direito de escolher. Invés de o debate eleitoral centralizar-se na importância da

[...] base normativa de defesa da democracia como valor em si [os candidatos insistiram em produzir uma] crise de governabilidade e uma constante instabilidade política que,

2 Essa tendência observada, se confirmada, leva à eleição de políticos egocêntricos e sem "um projeto global de sociedade. Maquiavel, já em 1512, alertou aos novos pretendentes de principados que, se só pensassem em si mesmos e não no estabelecimento da complexidade que envolve uma determinada tela de soberania, estariam fadados ao fracasso da sua do minaçáo" (Lima, 1999, p. 189).

3 Nesse quadro, foi sintomática a opção do Tribunal Superior Eleitoral em adotar como orientação para sua propaganda institucional, nesta eleição, o slogan: "Você decide quem contrata, você é o patrão. Vote!".

Debates do NER, Porto Alegre, ano 7, N. 10, P. 89-104, jul./Dez. 2006 
no longo prazo, poderá ter conseqüências regressivas no esforço da institucionalização democrática (Baquero, 1996, p. 139).

E completando esse quadro de restrição das possibilidades de percepção da questão ética e suas possíveis soluções, uma das propagandas institucionais do Tribunal Superior Eleitoral, veiculada na televisão durante a campanha eleitoral, pregava que, na hora de escolher nossos candidatos, devíamos desconsiderar as opiniōes que os outros nos apresentavam e decidir sozinhos. Ou seja: ao invés de debater nossas escolhas, as façamos em segredo. Eis aí o poder secreto e invisível, que é pretensamente denunciado como o grande mal, no governo, sendo colocado inversamente como modelo de orientação do auto-governo dos cidadãos, no momento do voto, tão ao gosto da cultura política e do neopopulismo institucionalizados em tempos de neoliberalismo (Baquero, 1996, p. 138).

Enfim, trata-se aqui do ethos privado mais do que da ética civil que, na definição de Cortina (1995, p. 8), "[...] es, en principio, la ética de los ciudadanos, es decir, la moral que los ciudadanos de una sociedad pluralista han de encamar paraque en ella sea posible la convivencia pacífica, dentro del respeto y la tol erancia por las diversas concepciones del mundo".

Deslocando a discussão da questão ética do campo de conflitos entre posicionamentos políticos e concepções de mundo para o da privatização das responsabilidades éticas, frente ao problema da corrupção, os discursos eleitorais não enfatizaram as deficiências da estrutura política e, muito menos, possibilitaram com que os princípios da ética civil assumissem um papel dominante no debate de projetos políticos de sociedade e de governo.

Assim, torna-se necessário perceber que os valores que subjaziam nos discursos eleitorais estruturavam-se em outra ordem de princípios.

\section{A POROSIDADE DAS ORIENTAÇÕES ÉTICAS ENTRE ESFERAS PLURALISTAS E CONCORRENCIAIS}

Aqui, estamos no ponto de perguntar, com Lipovetsky (2000, p. 10): se a questão ética está em evidência no debate eleitoral e político, mas este debate desloca sua discussão do campo de conflitos que lhe é próprio para o da privatização das responsabilidades éticas, de que natureza é este debate? Que princípios estruturam os discursos, neste debate, ou que valores os orientam?

Uma resposta possível a essas questões, mesmo que sem a pretensão de respondê-las plenamen te, está assentada no reconh ecimento da "porosidade" (Sanchis, 2001)4 que carac-

\footnotetext{
4 Sanchis elabora o termo no quadro de interpretação de uma porosidade das crenças na sociedade brasileira, buscando justificar uma concepção contemporânea de sincretismo sincrônico, distinto do sincretismo diacrônico que marcava as relaçōes tradicionais de conversão religiosa. Apropriome do termo, aqui, para buscar configurar uma ordem de interaçóes entre as esferas política e religiosa, que derivam da formação de um pluralismo concorrencial nas mesmas.
}

Debates do NER, Porto Alegre, ANo 7, N. 10, P. 89-104, JUl./DEZ. 2006 
teriza as influências recíprocas e contemporâneas entre as esferas política e religiosa (Velho, 2005). Sobretudo, no fato de ambas as esferas configurarem perspectivas pluralistas e concorrenciais cada vez mais abertas, entre si, e também com outras esferas contemporâneas de ação e produção de sentidos (Sanchis, 2002; Burity, 2002; Sarlo, 2005; Chekroun, 2005).

Assim, embora aceite o questionamento inicial de Lipovetsky, pretendo orientar esta elaboração em outra direção que a tomada por este autor, de que "a ética indolor dos novos tempos democráticos", em uma "sociedade pós-moralista", orienta-se pela inteligência, seguindo uma

[...] razón pragmática y experimental, menos exigentes para el individuo pero más eficaces socialmente, menos categóricas para las personas pero más apremiantes para las organizaciones, menos sublimes pero más aptas para responsabilizar a los hombres, menos puras pero susceptibles de corregir con mayor celeridad los diferentes excesos o indignidades de las democracias (Lipovetsky, 2000, p. 20).

Mais que constatar uma sociedade na qual a moral haveria se libertado de seus atributos absolutos - deveres - em proveito dos direitos, penso que o encontro proporcion ado pelo debate da questão ética entre a sociedade política e a religião, no Brasil, produz "uma outra lógica" (Parker, 1996). Para além da or ientação racional is ta de uma "ética prudente" indicada por Lipovetsky (apesar de muito instigante), esta outra lógica tem implicado na configuração de novas subjetividades e experiências políticas e religiosas, convergentes em "comu nidades de sentido" (Baczko, 1985).

Tal convergência pode ser constatada em duas ordens de fatores: primeiro, como indica Baquero (1996, p. 140),

Atualmente, não se pode negar que tanto elementos políticos como valores que se enraízam ao longo da vida de uma pessoa afetam sua percepção sobre o sistema político no qual ele está inserido. A conjugação desses dois conjuntos de valores pode ser determinante na efetiva consolidação de uma democracia. Isso implica que, mesmo em épocas de adversidades econômicas e turbulências sociais, a crença dos cidadãos de que no futuro as coisas serão melhores garante a durabilidade da democracia. [...] o modelo econômico aplicado parece estar criando um campo propício para uma reversão atitudinal dos cidadãos em relação a própria forma de governo.

Segundo, que essas crenças dos cidadãos enformam-se em "[...] campos de consciência [que] aparecem como uma constelação de fatos e significados daquilo que é cons cientemente vivenciado" (Sandoval, 1994, p. 61).

Nesse sentido, a configuração daquelas novas subjetividades e experiências se desdobra de um plano de interações entre as esferas de ação contemporâneas que se deslocaram da macro-política para mediações mais próximas e significativas às pessoas, na última década. Esse deslocamento gerou novas problematizaçôes no universo simbólico da política, mostrando que ele "[...] também é constituído pelas fontes mediatas e próximas de formação de classes” (Sandoval, 1994, p. 62).

Debates do NER, Porto Alegre, ANo 7, N. 10, P. 89-104, Jul./DeZ. 2006 
O movimento dessas interações, na sociedade brasileira, fez com que os princípios éticos transitassem no sentido de uma aproximação com as necessidades coletivas que se projetam na esfera pública, como demandas às políticas sociais (Pastorini, 1997), para onde confluem retritivamente a definição de "deveres não-absolutos". Esses deveres, contudo, possuem e expressam uma teleologia enraizada nas experiências pessoais e nos agrupamentos enformados em "campos problemáticos ativos" (Deleuze, 1988, p. 140) de luta contra as desigualdades.

Ou seja, a defesa dos direitos que está na base da discussão ética contemporânea não prescinde do dever, mas o nega como um absoluto exterior à experiência pessoal ou coletiva. E esse movimento implica na percepção de que

[...] Modalidades de consciência estão constantemente em processo de transformação, com a progressiva extinção das arcaicas, e a emergência de outras novas. A tarefa de analisar a consciência política deveria ser não apenas descritiva, em relacionando a consciência ao contexto das relaçôes de classe, mas também interpretativa enquanto se preste ao exame do declínio de certas formas de pensamento e o afloramento de outras, e o que significa esse processo dentro de um dado contexto de rearranjos sociais (Sandoval, 1994, p. 69).

Isso é o que vejo quando jovens católicos, simpatizantes de um partido político, se reúnem voluntariamente para discutir a questão ambiental e propor projetos de ação coletiva nessa linha, enquanto outro grupo de simpatizantes do mesmo partido, formado por jovens luteranos, se reúne para discutir e propor projetos e açóes em torno da questão da violência 5 . Em geral, o que distingue essas diferenças restritas pode ser reconhecido na trajetória pessoal ${ }^{6}$ de tais jovens e em suas inserções na lógica de produção e reprodução das desigualdades sócio-territoriais. Esse é o sentido que vem sendo observado, também, nos estudos sobre a caracterização do "novo voluntariado" (Silva, 2004), na nos sa sociedade.

Nessesentido, a ilusãoda boasociedadenão se perdeu, mas se tomoudifusaem idealizações, identificações e projeçōes (Bertrand, 1989) mais próximas ou mais distantes das experiências das pessoas, de forma que se expressa, inversamente, nas relaçôes e mediaçōes que os indivíduos estabelecem com a estrutura política da sociedade (Sandoval, 1994, p. 59-60).

Essa mudança interfere decisivamente na estrutura política, de forma que o crescimento do PT, nas últimas décadas, poderia ser explicado, também, por seu pluralismo de unidade programática na coexistência da diversidade ideológica. Tal composição partidá-

5 Aqui, trata-se de percepções pessoais elaboradas sobre o acompanhamento que realizo junto a grupos religiosos voluntários de jovens simpatizantes do PT, em São Leopoldo, RS, desde o início de 2006.

6 Alguns estudos sobre a ação social voluntária, na contemporaneidade, têm enfatizado essa relação entre as experiências biográficas e a motivação dos sujeitos voluntários para atuar em áreas específicas e de forma direta na relação com aqueles privados de proteção social (Lopes, 2002). Essa percepção escapou a Lipovetsky (2002, p. 144), ao considerar que “[...] es sobre todo el placer de encontrar al otro, es deseo de valorización social, la ocupación del tiempo libre lo que constituyen las motivaciones esenciales del voluntariado".

Debates do NER, Porto Alegre, ANo 7, N. 10, P. 89-104, Jul./DEZ. 2006 
ria configurou uma hierarquia que trata as diferenças sem as anular, constituindo instâncias decisórias baseadas em um jogo de reconhecimento e em um acordo de proporcionalidade representativa dessas diferenças na constituição dos governos, como ficou caracterizado nas gestôes municipais do partido, em Porto Alegre.

E independente do PT, hoje, manter ou não esse princípio, é possível projetar uma correspondência desse modelo pluralista para a lógica das eleições, nesta campanha.

Assim, enquanto na campanha eleitoral para deputados estaduais e federais eram visíveis a pluralidade e a concorrência religiosas nos discursos dos candidatos, na disputa para governador, senador e Presidente da República os discursos tendiam a acentuar mais a pluralidade que a concorrência. Em alguns casos, a questão religiosa nem sequer veio à tona, como se o pluralismo religioso no Brasil fosse um "problema resolvido".

Os movimentos estratégicos das campanhas dos candidatos aos cargos majoritários, entretanto, mostrou uma preocupação maior com esse pluralismo concorrencial do que os seus discursos.

Entre as várias coberturas jornalísticas do período, uma matéria assinada por Chico Silva (2006), na revista Istoé, in titulada "Eleiçōes 2006. A política e a religiāo", traz informaçōes valiosas.

A matéria teve o mérito de evidenciar que fé e política, eleição e religião, no Brasil, são elementos que mantêm ligação. Em um país onde 100 milhơes de pessoas adultas se declaram praticantes de algum tipo de religião, as atitudes e afirmações dos candidatos frente a essa relação trazem conseqüências nas urnas.

Na medida em que tais atitudes e afirmações tran sita m na "porosidade", mas se combinam segundo projeções em uma hierarquia sobre a importância dos cargos em eleição, é no topo dessa hierarquia que tais combinações devem ser mais bem apreendidas.

O que se constata nesse topo, ou seja, na campanha para Presidente da República? Silva (2006) responde: "Em cima dos púlpitos, à sombra da cruz ou com o terço nas mãos, os candidatos têm procurado os templos e os líderes religiosos para buscar apoios e deixar claro que, sim, são crentes".

E se há algo que se evidenciou nessa eleição, é justamente essa clareza. Os três principais candidatos à Presidência da República têm trajetórias conhecidas, nesse sentido: Lula se declara católico fervoroso e sempre foi ligado à ala progressista do catolicismo brasileiro; Alckmin, por usa vez, além de reconhecidamente católico, tem relações de adesão (que ele busca negar) com a Opus Dei, ala conservadora do catolicismo; já Heloísa Helena vincula-se a uma concepção socialista católica e oscila entre o catolicismo devocional e suas tendências pentecostais. E embora esta última tenha evitado transitar por igrejas e líderes religiosos durante a campanha eleitoral, seu discurso sobre a questão ética foi o mais veemente na tradução dos valores cristãos, baseado em um dos dez mandamentos, que a candidata repetia em suas aparições na televisão: "eu sempre falo para as crianças: é proibido roubar"'.

7 Os discursos de campanha da candidata reforçaram essa tradução dos valores cristãos em várias oportunidades, com frases como "O que o governo faz com o povo sofrido é uma traiçáo", "É preciso ter honra", "Estou em uma cruzada pela cidadania" e "Combati o bom combate".

Debates do NER, Porto Alegre, ANo 7, N. 10, P. 89-104, Jul./DeZ. 2006 
Já os dois principais concorrentes à Presidência, que se projetaram ao segundo turno, não só visitaram igrejas e líderes religiosos, como organizaram estratégias específicas de atração dos votos de religiosos, "sobretudo dos evangélicos, cuja tradição no controle dos

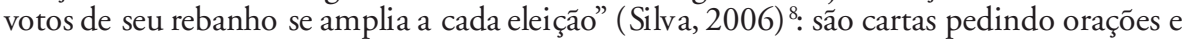
votos, comitês especiais de campanha para religiosos, coligaçóes com partidos controlados por igrejas e líderes, encomenda de pesquisas de intenção de voto com recorte nessa categoria de eleitores e monitoramento de documentos, matérias jornalísticas e manifestaçóes públicas de líderes religiosos.

Enfim, um aparato estratégico que permite que os candidatos ajustem seus discursos ou suas açôes de campanha aos movimentos mais ou menos receptivos desses eleitores e aliados.

Essa via de recepção, porém, é de mão dupla, ou seja, não se trata somente de candidatos à Presidência caçando votos, também há que se considerar que, cada vez mais, candidatos e políticos reconhecem que

[...] "la sombra de Dios es larga", es decir, que esos valores siguen presentes en nuestra cultura, aunque Dios haya muerto, porque están encarnados en las proclamas sobre los derechos humanos, sobre la igualdad y la solidariedad [...]

La reanimación de nuestras sociedades - y entiendo "reanimación" como sinónimo de "moralización" - exige entonces, según hemosvenido diciendo, recordar los bienes internos de las distintas actividades y tratar de adquirir las virtudes necesarias para alcanzarlos" (Cortina, 1995, p. 49).

Assim, os próprios candidatos transitam pela "porosidade" das interações entre as esferas políticas e religiosas, por exigência da lógica pluralista de nossa sociedade. Com exceção de alguns candidatos, nessa campanha eleitoral, que ainda sobrevivem de nichos políticos residuais ou tradicionais, a maioria partilhou desse processo, definido por Duarte (2005, p. 144) como de "negociação da realidade":

A idéia de uma "negociação da realidade" sublinha a qualidade complexa, conflitiva ou contraditória do horizonte de possibilidades em que se movem os sujeitos das sociedades modernas em suas decisões éticas. Isso envolve em primeiro lugar a mencionada preemin ên cia do "pluralis mo", implicada no valor da liberd ade. Mas acent ua sobretud o a dimensão dialogal que tendem a assumir todos os atos (inclusive os mais subjetivos) num contexto como esse.

Daí o trânsito pela "porosidade" das interações entre as esferas polític as e religiosas, no topo dessa hierarquia eleitoral. Trata-se de administrar o pluralismo, em benefício da razão pública, justamente onde eles parecem se afastar, porque

8 Uma matéria coletada no site http://noticias.terra.com.br/eleicoes2006/interna/0,,OI1183447EI6651,00.html, em 10/10/2006, mostra que esse controle se exerce também sobre os candidatos: "A Universal havia proibido a candidatura à reeleição de parlamentares sob suspeita (na CPI dos Sanguessugas). Com isso, perdeu 14 postulantes a mais quatro anos na Câmara. Apenas dois membros da igreja tentaram - sem sucesso - a reeleiçáo".

Debates do NER, Porto Alegre, ANo 7, N. 10, P. 89-104, Jul./DEZ. 2006 
[...] Os elementos constituintes do discurso religioso e político não possuem sentido em si mesmos; dependem de sua articulação concreta, a partir de situações de antagonismo, nas quais uma "questão" ou um "ator" aparecem como ética ou politicamente desafiadores ou ameaçadores e desencadeiam a aglutinação de diferentes visões ou atores em campos adversos. [...] O intercurso entre o discurso democrático e o religioso permite diferentes articulaçôes e significados para os "mesmos" elementos, dependendo de em qual dos campos em disputa se esteja (Burity, 2002, p. 32).

E aqui devo considerar, para encerrar, que as articulações e significados da questão ética, nessa campanha eleitoral, moveram mais os discursos (dos) políticos que a participação da militância partidárias, como em campanhas anteriores.

\section{ESFERAS ÉTICAS CONTEMPORÂNEAS: PARTICIPAÇÃO E POLÍTICA NA ERA PÓS-MILITÂNCIA}

Os momentos anteriores desta elaboração evidenciaram um duplo recorte acerca do debate da questão ética, na campanha eleitoral de 2006. A constatação de que tal debate transitou por uma hierarquia dos cargos em eleição, adquirindo centralidade nos discursos eleitorais em disputa pelos cargos majoritários, possibilitou primeiramente mostrar que a priva tização das responsabilidades éticas abafa a "predisposição para intervenção" da população. Ao restringir o repertório disponível das ações individuais e coletivas de enfrentamento da questão ética ao voto, os discursos dos candidatos reforçaram a desorganização política da sociedade civil, institucionalizada pelas políticas neoliberais nas últimas décadas.

Nessa direção e em suas várias facetas, a campanha eleitoral se desenvolveu em conformidade com "[...] uma política ativa de redução da sociedade civil a um agregado de indivíduos atomizados, cujo poder de barganha ficaria reduzido ao limite de suas possessôes individua is" (Baquero, 1996, p. 135).

Essa paisagem societária predispõe alguns analistas a afirmar estarmos vivendo um período de apatia política, provocada pelo desencantamento da militância, pelo retrocesso na participação e pelo embotamento da indignação social, frente às crises de governabilidade, como na crítica de Vitullo (1999, p. 42-43) a alguns teóricos da democracia participativa.

$\mathrm{O}$ argumento central dessas análises é que o excesso de participação é prejudicial à democracia e que a participação contida na "normalidade institucional" e democrática (como aquela em que ocorreram as eleições de 2006, segundo o TSE) é garantia de governabilidade. Tudo se passa como se a política tivesse inaugurado uma fase de "pósmilitância" apática. Ocorre que "[...] a apa tia não é uma escolha do indivíduo senão uma clara manifestação de sua impotência, gerada pela sociedade” (Vitullo, 1999, p. 43).

Assim, esse primeiro recorte estaria afetado, em princípio, pela "[...] violenta reasserção do determinismo econômico na vigência do neoliberal ismo” (Burity, 2002, p. 36). Contudo, como o próprio Burity aponta (Burity, 2002, p. 36),

Debates do NER, Porto Alegre, ANo 7, N. 10, P. 89-104, Jul./DeZ. 2006 
[...] encontram-nos, por toda parte, com um mal-estar explícito diante das explicações deterministas e objetivistas, em favor de uma postulação do caráter construído de toda ordem (social, política, cultural). Construção onde o simbólicoldiscursivo e o material são coextensivos, onde o sentido e as práticas se articulam permanentemente e tecem o real.

A pretensão do segundo recorte desta elaboração foi justamente na direção desta postulação. Busquei relacionar o trânsito que marcou o debate da questão ética, nesta eleição, com a "porosidade" das interaçōes entre as esferas política e religiosa, para evidenciar tratar-se mais de uma "negoc iação da realidad e" que se impõe na hierarquia dos cargos em eleição, entre aqueles que buscam governar sociedades pluralistas e aqueles que buscam eleger seus governantes.

Embora a paisagem societária institucionalizada pelo neoliberalismo deva ser reconhecida em sua importância, reduzir o debate da questão ética que caracteriza a crise de nossas instituiçôes políticas a um determinismo econômico seria, no mínimo, um estreitamento de interpretação. Sociedades pluralistas como a brasileira, mesmo que convivendo com altos índices de desigualdade social, apresentam uma complexidade de interaçōes entre as dimensões simbólico/discursivas e materiais da vida coletiva. Tal complexidade se projeta ou exterioriza cada vez mais como normas e valores sociais descentradas “[...] de uma concepção de sociedade como totalidade para o território de vivência e concorrência entre múltiplos ethoi, no espaço plástico e móvel do social” (Burity, 2002, p. 36).

E mesmo que essa projeção/exteriorização seja cada vez mais "[...] definida como um processo constante de produção de sentido inseparavelmente ligado a práticas individuais e coletivas, por meio das quais a realidade social se constitui” (Burity, 2002, p. 36), é importante seguir a orientação de

[...] manter a conexão entre a identificação dos “interesses" dos atores e a experiência concreta das determinaçôes histórico-sociais por parte desses últimos, a qual é mediada culturalmente. Desta forma, a postulação da autonomia cultural no plano analítico pode ser "demonstrada" por meio da análise da medida em que as pessoas fazem sentido (mediação cultural) das condições de sua experiência no processo de se posicionarem e agirem no mundo (Burity, 2002, p. 37) .

É nesse sentido que a permanência do reconhecimento dos deveres, por parte de indivíduos e grupos, mesmo que sem seus atributos absolutos, evita que todos os problemas sociais sejam tratados localmente, ou reduzidos a questóes tribais. Como indica Cortina (1995, p. 13),

9 Burity indica, para além da relação entre a ação e seu sentido na tradição weberiana, um outro referencial que joga com dois elementos: o reconhecimento do outro como dotado de singularidade e integridade, que leva ao respeito de sua alteridade (posição que lembra muito os argumentos da "luta por reconhecimento", de Honneth [2003]), e a compreensão de que ele "[...] se define sempre pela sua posição num dado sistema de significação e práticas - que chamo discurso" (2002, p. 37, nota 6).

Debates do NER, Porto Alegre, Ano 7, n. 10, P. 89-104, JUl./Dez. 2006 
[...] los problemas morales de una sociedad pluralista y multicultural exigen respuesta a esa sociedad en su conjunto y no sólo a una parte de ella, y que si queremos que las leyes no se hagan a espaldas de la sensibilidad moral de uno o varios sectores de la población, urge tratar de detectar cuáles son nuestros valores morales compartidos ${ }^{10}$.

A formação da sociedade pluralista brasileira tem evidenciado que o avanço da concorrência religiosa é um fator de modernidade, que estabelece correspondências homólogas com a modernidade política e a cultural (Burity, 2002). Se tais correspondências se evidenciaram no debate da questão ética, nesta eleição, é porque elas se projetaram das expectativas que caracterizam as esferas éticas contemporâneas, difusas nos campos de ação, mas convergentes em torno da exigência do que é moralmente justo. Isso por que

[...] Cuando tengo algo por justo no estoy pretendiendo sólo expresar un sentimiento mio [...]. Estoypretendiendo, por el contrario, que lo tenga por justo cualquier ser racional que se sitúe en condiciones de imparcialidad; es decir, estoy pretendiendo que debe tenerlo por justo cualquier ser racional que no se deje llevar por sus intereses individuales o grupales, sino por los intereses universalizables, porque creo tener razones suficientes para convencerlo de que mi propuesta satisface tales intereses (Cortina, 1995, p. 64).

Essa pretensão de justiça está na base da "negociação da realidade" que caracteriza e sustenta o debate da questão ética contemporânea. Para além da superação de uma ética cen trada no bem, em proveito de uma centrada no bem-estar, ou "ética mínima", como sugere Lipovetsky (2002, p. 50-53, p. 129-133), considero mais consistente, para pensar o caso brasileiro, a percepção de Cortina $(1995$, p. 65) de que se trata de uma distinção entre éticas de mínimos e éticas de máximos:

Las éticas de la justicia o éticas de mínimos se ocupan únicamente de la dimensión universalizable del fenómeno moral, es decir, de aquellos deberes de justicia que son exigibles a cualquier ser racional y que, en definitiva, sólo componen unas exigencias mínimas. Las éticas de la felicidad, por el contrario, intentan ofrecer ideales de la felicidad, en los que el conjunto de bienes de que los hombres podemos gozar se presentan jerarquizadamente como para producir la mayor felicidad posible. Son, por tanto, éticas de máximos, que aconsejan seguir su modelo, nos invitan a tomarlo como orientación de la conducta, pero no pueden exigir que se siga, porque la felicidad es cosa de consejo e invitación, no de exigencia.

${ }^{10}$ Cabe pensar, aqui, que esta premência ética difundida socialmente está na base mesma dos argumentos daqueles que defendem a implantação do voto distrital para deputados estaduais e federais, mantendo-se a eleição universal e direta para os cargos majoritários. O voto distrital teria um objetivo, entre outros, de evitar que os candidatos privatizassem as responsabilidades éticas em seu proveito.

Debates do NER, Porto Alegre, ANo 7, n. 10, P. 89-104, Jul./Dez. 2006 
Essa distinção é o que percebo, na campanha eleitoral de 2006. A discussão sobre a questão ética e seu trânsito por entre a hierarquia de cargos em eleição mostrou-se como síntese das interaçôes pluralistas e concorrenciais entre as esferas políticas e religiosas. A cada cargo em eleição era projetada a faceta mais próxima ou mais distante de reconhecimento da sua importância, nas escalas hierárquicas que conformam sua inserção nos "campos problemáticos ativos" que se reproduzem da quelas in teraçôes. Se os ataques se cen tralizaram na eleição do cargo majoritário, é porque em tal cargo conta mais o reconhecimento das capacidades para administrar a pluralidade, sem anular a concorrência.

Nesse sentido, política e religião se confirmam como esferas abertas a interações recíprocas, que moldam os sentidos e discursos institucionais às formas como se expressam e projetam sobre as mesmas as práticas individuais e coletivas que retomam ênfases éticas na politicidade e religiosidade dos atores contemporâneos.

\section{REFERÊNCIAS}

BACZKO, Bronislaw (1985). A imaginação social. In: Enciclopédia Einaudi. Edição portuguesa, Imprensa Nacional - Casa da Moeda.

BAQUERO, Marcello (1996). Cultura política e neoliberalismo na América Latina. In: PINTO, Céli R.; GUERRERO, Hugo (orgs.) América Latina: o desafio da democracia nos anos 90. Porto alegre: Editora da Universidade/UFRGS; Associação de Universidades Grupo Montevideo.

BERTRAND, Michele (1989). O homem clivado - a crença eo imaginário. In: SILVEIRA, Paulo e DORAY, Bernard (orgs.) Elementos para uma teoria marxista da subjetividade. São Paulo: Vértice.

BOBBIO, Norberto (1995). Direita e esquerda; razôes e significados de uma distinção política. São Paulo: Editora Unesp.

(1986). O futuro da democracia; uma defesa das regras do jogo. 5.ed. Rio de Janeiro: Paz e Terra.

BOURDIEU, Pierre (1991). La distinción; critério y bases sociales del gusto. Madrid: Taurus.

BURITY, Joanildo (2002). Mudança cultural, mudança religiosa e mudança política: para onde caminhamos? In: BURITY, Joanildo (org.) Cultura e identidade; perspectivas interdisciplinares. Rio de Janeiro: DP\&A.

CHEKROUN, Mohammed (2005). Socio-economic changes, collective insecurity and new forms of religious expression. Social Compass, Louvain, 52 (1), p. 13-29.

CORTINA, Adela (1995). Ética civil y religión. Madrid: PPC Editorial.

DELEUZE, Gilles (1988). Repetição e diferença. São Paulo: Graal. 
DUARTE, Luiz F. D. (2005). Ethos privado e justificação religiosa. Negociações da reprodução na sociedade brasileira. In: HEILBORN, Maria L.; DUARTE, Luiz F. D.; PEIXOTO, Clarice; BARROS, Myriam L. (orgs.) Sexualidade, familia e ethos religioso. Rio de Janeiro: Garamond.

GIRARDET, Raoul (1987). Mitos e mitologias politicas. São Paulo: Cia das Letras.

GODELIER, Maurice (1974). Hierarquias nas sociedades primitivas e antropologia econômica. In: AGUIAR, Neuma. Hierarquias em classes. Rio de Janeiro: Zahar.

HABERMAS, Jürgen (2004). A inclusão do outro; estudos de teoria política. 2.ed. São Paulo: Loyola.

HONNETH, Axel (2003). Luta por reconhecimento, a gramática moral dos conflitos sociais. São Paulo: Editora 34.

KANT, Imanuel (1992). A paz perpétua e outros opúsculos. Lisboa: Ed 70.

LIMA, Gilson (1999). O dilema de vivermos uma época que agoniza. In BAQUERO, Marcello (org.). Desafios da democracia na América Latina; debates sobre cultura política. Porto Alegre: Editora da Universidade/UFRGS/Centro Universitário La Salle.

LIPOVETSKY, Gilles (2000). El crepúsculo del deber, la ética indolora de los nuevos tiempos democráticos. 5.ed. Barcelona: Editorial Anagrama.

LOPES, José Rogério (2002) Ação voluntária: o sal da terra e a abertura para o outro (Prefácio). In: SILVA, J. O.; FEITOSA, S. Ação social voluntária: motivação e evasão. Cadernos CEDOPE, no 19, São Leopoldo: Unisinos.

PARKER, Cristián (1996). Religião popular e modernização capitalista; outra lógica na América Latina. Petrópolis: Vozes.

PASTORINI, Alejandra (1997). Quem mexe os fios das políticas sociais? Avanços e limites da categoria "concessão-con qu ista". Serviço Social \& Sociedade, São Paulo, Vol. 18, no 53, p. $80-101$.

RIBEIRO, Renato Janine (2006). Democracia é maior que qualquer um de nós. Revista Fórum. http://www.revistaforum.com.br/vs3/artigo_ler.aspx?artigo=8882ffe3-fde3-4e888012-6076a8b49ef9\&pagina $=\&$ Query $=\& A s s u n t o=\& E$ dicao $=\&$ Autor $=($ coletadoem $04 / 10)$.

SANCHIS, Pierre (1997). Campo religioso contemporâneo no Brasil. In ORO, Ari Pedro e STEIL, Carlos Alberto. Globalização e religião. Petrópolis: Vozes. EDUERJ. (2001). Fiéis e cidadãos; percursos do sincretismo no Brasil. Rio de Janeiro:

. (2002). Religiões no mundo contemporâneo: convivência e conflitos. Ilha, Florianópolis, Vol. 4, nº 2, p. 5-23.

SANDOVAL, Salvador (1994). Algumas reflexões sobre cidadania e formação de consciência política no Brasil. In: SPINK, Mary Jane Paris (org.). A cidadania em construção; uma reflexão interdisciplinar. São Paulo: Cortez. 
SARLO, Beatriz (2005). Tempo presente; notas sobre a mudança de uma cultura. Rio de Janeiro: José Olympio.

SILVA, Jacqueline O. (org.) (2004) Novo voluntariado social; teoria e ação. Porto Alegre: Da Casa Editora.

SILVA, Chico (2006). A política e a religião. Revista Istoé(versão on line). www.terra.com.br/ istoe//1923/brasil/1923_politica_e_a_religiao.htm (coletado em 30/08).

VELHO, Otávio (2005). Ciências sociais e religião. IHU On-Line, São Leopoldo, RS, no 169, p. 10-13, dez.

VITULLO, Gabriel E. Saindo do marasmo acadêmico: reflexões sobre cultura política e as teorias da democracia participativa. In BAQUERO, Marcello (org.). Desafios da democracia na América Latina; debates sobre cultura política. Porto Alegre: Editora da Universidade/ UFRGS; Centro Universitário La Salle. 